\title{
PERAN KOMPETENSI KEWIRAUSAHAAN KEPALA SEKOLAH DALAM PENINGKATAN MUTU PENDIDIKAN DI SMP N 3 JETIS, BANTUL
}

\author{
Wiyatno, Muhyadi \\ SMP Muhammadiyah Merauke Papua; Universitas Negeri Yogyakarta \\ wiyatno59@ymail.com; muhyadi@uny.ac.id.
}

\begin{abstract}
Abstrak
Penelitian ini bertujuan untuk mengetahui peran kompetensi kewirausahaan kepala sekolah di SMPN 3 Jetis, Bantul, tahun pelajaran 2012/2013 dilihat dari: 1) konteks, 2) input, 3) proses, dan 4) produk dari peran kompetensi kewirausahaan kepala sekolah. Data dikumpulkan melalui wawancara, dan dianalisis secara deskriptif. Peran kompetensi kewirausahaan kepala sekolah dalam peningkatan mutu pendidikan dapat dilihat melalui penelitian model CIPP. Konteks untuk mengetahui relevansi kebijakan program dengan kebutuhan sekolah. Input untuk mengidentifikasi kesiapan sekolah. Proses untuk mengetahui pelaksanaan kegiatan sekolah. Produk untuk mengetahui seberapa besar mutu sekolah, dalam bentuk jumlah lulusan. Hasil penelitian adalah sebagai berikut: 1. Konteks baik, karena relevansi program sesuai dengan kebutuhan sekolah. 2. Input baik, berupa kesiapan sekolah yang meliputi: sarana prasarana, guru, siswa, dan kepala sekolah, untuk melaksanakan program dan sasaran yang jelas. 3. Proses pelaksanaan program baik, karena partisipasi guru, dan siswa, kualitas kegiatan belajar mengajar, dan ekstrakurikuler meningkat, dan kepala sekolah mampu mengelola semua kegiatan sekolah. 4. Produk baik, berupa: (a) prestasi akademik dalam perolehan nilai ujian nasional, (b) prestasi non-akademik, dan (c) siswa menjuarai berbagai lomba, demikian peran kompetensi kewirausahaan KS dikatakan baik dan sukses.
\end{abstract}

Kata Kunci : kompetensi, kewirausahaan, kepala sekolah.

\section{THE ROLE OF THE PRINCIPAL'S ENTREPRENEURSHIP COMPETENCY IN IMPROVING THE EDUCATION QUALITY OF SMP N 3 JETIS, BANTUL}

\section{Abstract}

This research aims to reveal the role of the principal's entrepreneurship competency in the SMP 3 Jetis, Bantul, in 2012/2013 viewed from: 1) context, 2) input, 3) process, and 4) product of the role of the principal's entrepreneurship competency. The data were collected through interviews, and analyzed descriptively. The role of the principal's entrepreneurship competency in improving the quality of the education can be seen through the CIPP models of the research. Teh context is to determine the relevance of the program to the needs of the school policy. The input is to identify the school readiness. The process is for determining the school activities. The product is to determine the quality of the school in terms of the number of graduates. The results are as follows 1 . The context is good, because of the relevance of the program according to the needs of the school. 2. The input is good, in the form of school readiness including: infrastructure, teachers, students, and principals to implement the program with clear targets. 3 . The program implementation process is good, because the participation of teachers and students, quality of teaching, extracurricular increased, and the principals are able to manage all school activities. 4. The product is good, in the form of: (a) academic achievement in the National Examination achievement, (b) non academic achievement, and (c) students' winning various competitions. There fore the role of the principal's entrepreneurship competency is said to be good and successful.

Keywords: competency, entrepreneurship, the principal's 


\section{Pendahuluan}

Pendidikan merupakan salah satu upaya untuk membangun dan meningkatkan mutu SDM menuju era globalisasi yang penuh dengan tantangan, sehingga disadari bahwa pendidikan merupakan sesuatu yang sangat fundamental bagi setiap individu. Oleh karena itu, kegiatan pendidikan tidak dapat diabaikan begitu saja, terutama dalam memasuki era persaingan yang semakin ketat, tajam, berat pada abad millenium ini (Veithzal Rivai dan Sylviana Murni, 2010, p.1).

Sekolah menjadi tumpuan utama, pada tataran pendidikan Dasar khususnya bangku Sekolah Menengah Pertama sebagai dasar untuk meningkatkan ke jenjang pendidikan berikutnya. Maka Kepala Sekolah SMP dituntut untuk melakukan inovasi, kreativitas, dan improvisasi. Untuk menyiapkan lulusan SMP yang memenuhi kompetensi lulusan, perlu terus diperbaiki atau ditingkatkan kualitas pembelajarannya.

Kepala Sekolah yang tidak memiliki kompetensi didasarkan pada standar kompetensi Kepala Sekolah atau kemampuan yang harus dimiliki, belum tentu mampu menjalankan tugasnya sebagai Kepala Sekolah yang akan mengakibatkan kepemimpinannya tidak profesional. Kepala Sekolah bukan manajer sebuah unit produksi yang menghasilkan barang mati, melainkan memimpin pendidikan yang bertanggung jawab untuk membentuk manusia yang berkualitas. Secara ilmu pengetahuan dan moral, mampu menciptakan lingkungan belajar yang kondusif, serta mampu meningkatkan kinerja guru. Utamanya ia harus mampu memimpin sekolah, dalam rangka pendayagunaan sumber daya sekolah secara optimal.

Setiap kepala sekolah memiliki tanggung jawab penuh terhadap seluruh aspek operasional penyelanggaraan sekolah. Mulai dari perencana, pelaksana, sampai pada kepengawasan. Untuk menjalankan tugasnya tersebut, seorang kepala sekolah wajib memiliki kompetensi kepribadian, manajerial, kewirausahaan, super- visi, dan sosial (Permendiknas nomor 13 tahun 2007).

Kepala sekolah dalam menjalankan tanggung jawabnya hendaknya memahami perannya sebagai seorang pemimpin pendidikan (Aan Komariah, 2006, p.123). Dalam perspektif kebijakan pendidikan nasional (Kepmendiknas RI Nomor 162/U/ 2003, Pasal 9 ayat 2), terdapat tujuh peran utama kepala sekolah, yaitu sebagai: (1) pendidik, (2) manajer, (3) administrator, (4) penyelia, (5) pemimpin, (6) pencipta iklim kerja, dan (7) wirausahawan.

Kepala Sekolah merupakan salah satu komponen yang paling berperan dalam meningkatkan kualitas pendidikan (E. Mulyasa, 2007, p.24). Membentuk sekolah yang efektif memerlukan proses dan waktu, serta kompetensi-kompetensi yang harus dimiliki oleh seorang pimpinan sekolah. Sekolah yang efektif merupakan lembaga yang tertata dengan rapi, berdasarkan konsep manajemen yang baik. Penanganan manajemen itu misalnya: manajemen sekolah, manajemen personal, manajemen kesiswaan, manajemen sumber daya manusia, manajemen kurikulun, manajemen humas, manajemen sarana prasarana pendidikan, manajemen pendanaan, manajemen evaluasi pembelajaran, manajemen supervisi, manajemen kewirausahaan kepala sekolah dan pengelolaan hal-hal yang mendukung proses pembelajaran di sekolah tersebut.

Kepala sekolah dengan kompetensi yang dimilikinya harus mampu memimpin sekolah dalam rangka pendayagunaan sumber daya sekolah secara optimal. Seorang pemimpin dikatakan sebagai entrepreneur, ia harus kreatif, inovatif, bekerja keras, ulet, dan memiliki naluri kewirausahaan. Kompetensi kewirausahaan yang diharapkan dicapai oleh kepala sekolah berdasarkan hasil revisi atas masukan Peraturan Menteri Pendidikan Nasional Nomor 13 tahun 2007 tentang Standar Kompetensi Kepala Sekolah/Madrasah adalah:

- Menciptakan inovasi yang berguna bagi pengembangan sekolah. 
- Bekerja keras untuk mencapai keberhasilan sekolah sebagai organisasi pembelajar yang efektif.

- Memiliki motivasi yang kuat untuk sukses dalam melaksanakan tugas pokok dan fungsinya sebagai pemimpin satuan pendidikan.

- Pantang menyerah dan selalu mencari solusi terbaik dalam menghadapi kendala yang dihadapi sekolah.

- Memiliki naluri kewirausahaan dalam meningkatan mutu pendidikan.

Salah satu konsep peningkatan mutu adalah teori effective school yang lebih memfokuskan pada perbaikan proses pendidikan (Edmonds, 1979, p.12). Beberapa indikator menunjukkan karakter dari konsep peningkatan mutu antara lain sebagai berikut: (1) lingkungan sekolah yang aman dan tertib, (2) sekolah memiliki misi dan target mutu yang ingin dicapai, (3) sekolah memiliki kepemimpinan yang kuat, (4) adanya harapan yang tinggi dari personel sekolah untuk berprestasi, (5) adanya pengembangan staf sekolah sesuai dengan tuntutan perkembangan ilmu dan teknologi, (6) adanya pelaksanaan evaluasi yang kontinyu dan dimanfaatkan sebagai penyempurnaan/perbaikan mutu, dan (7) adanya komunikasi dan dukungan intensif dari orang tua murid/masyarakat.

Peran kepemimpinan pendidikan adalah kegiatan mempengaruhi pengikut dalam rangka mengembangkan dan memajukan sekolah. (Wuradji, 2008, p.2). Berdasarkan data prasurvei yang diperoleh dari tanggal 26 Juli sampai dengan 28 Juli 2011, diketahui keberhasilan kepala sekolah SMP Negeri 3 Jetis, Bantul, Yogyakarta dalam mengembangkan kepemimpinan kepala sekolah. Indikasinya antara lain: (1) sebagian besar para siswa, guru, karyawan datang dan pulang pada waktunya, (2) KBM berjalan efektif dan efisien, (3) para guru, karyawan, dan siswa saling menyapa, tersenyum, dan menghormat (4) guru dan siswa melaksanakan sholat Dzuhur di mushola sekolah, (5) lingkungan sekolah tampak bersih walaupun masih dijumpai bungkus makanan kecil di selokan dan teras sekolah, dan (6) kegiatan ekstrakurikuler maupun ko kurikuler berjalan efektif misalnya kegiatan pramuka, PMR, maupun lainnya operasional dengan baik

Pengertian kepala sekolah

Permendiknas Nomor 28 Tahun 2010 tentang Penugasan Guru sebagai Kepala Sekolah/Madrasah pada Bab I pasal 1 bahwa kepala sekolah adalah guru yang diberi tugas tambahan untuk memimpin Taman Kanak-Kanak/Raudhotul Athfal (TK/RA), Taman Kanak-Kanak Luar Biasa (TKLB), Sekolah Dasar/Madrasah Ibtidaiyah (SD/MI), Sekolah Dasar Luar Biasa (SDLB), Sekolah Menengah Pertama/Madrasah Tsanawiyah (SMP/MTs), Sekolah Menengah Pertama Luar Biasa (SMPLB), Sekolah Menengah Atas/Madrasah Aliyah (SMA/MA), Sekolah Menengah Kejuruan/ Madrasah Aliyah Kejuruan (SMK/MAK), atau Sekolah Menengah Atas Luar Biasa (SMALB) yang bukan Sekolah Bertaraf Internasional (SBI) atau yang tidak dikembangkan menjadi sekolah bertaraf internasional (SBI).

Berdasarkan beberapa pengertian di atas dapat disimpulkan bahwa kepala sekolah adalah jabatan pimpinan, yaitu tenaga fungsional guru yang diberi tugas dan tanggung jawab serta mempunyai kemampuan untuk memimpin segala sumber daya yang ada pada suatu sekolah sehingga dapat didayagunakan secara maksimal untuk mencapai tujuan bersama.

Kepala sekolah dalam periode tertentu biasanya 4 (empat) tahun memiliki kekuasaan yang lebih besar untuk mengambil keputusan berkaitan dengan kebijakan pengelolaan sekolah. Kekuasaan yang lebih besar yang dimiliki kepala sekolah dalam pengambilan keputusan perlu dilaksanakan dengan demokratis antara lain dengan :

- Melibatkan semua pihak, khususnya guru dan orang tua murid

- Membentuk tim kecil di level sekolah yang diberi kewenangan untuk mengambil keputusan yang relevan dengan tugasnya. 
- Menjalin kerjasama dengan organisasi di luar sekolah.

\section{Kedudukan Kepala Sekolah}

Kedudukan Kepala Sekolah, sebagai pemimpin di sekolah yang dipimpinnya, antara lain :

- Kepala sekolah bekerja sama, sematamata untuk memberikan pelayanan kemanusiaan bukan untuk kepentingan pribadi.

- Memiliki pemahaman serta keterampilan yang tinggi

- Memiliki lisensi hukum dalam memimpin sekolah.

- Memiliki publikasi yang dapat melayani para guru sehingga tidak ketinggalan zaman.

- Mengikuti aneka kegiatan seminar pendidikan/pelatihan.

- Jabatannya sebagai suatu karier hidup dan

- Memiliki nilai dan etika yang berfungsi se-cara nasional maupun lokal.

Peran Kepala sekolah

Peran kepala sekolah adalah mengelola penyelenggaraan kegiatan pendidikan dan pembelajaran di sekolah. Kepala sekolah sebagai pemimpin di bidang pendidikan haruslah mengetahui dan memahami serta mengaplikasikan fungsi dan tugasnya dengan baik. Secara lebih operasional tugas pokok kepala sekolah mencakup kegiatan menggali dan mendayagunakan seluruh sumber daya sekolah secara terpadu dalam kerangka pencapaian tujuan sekolah. Jika seorang kepala sekolah mengetahui secara jelas tugas pokok dan fungsinya, maka seterusnya juga harus mampu mengembangkan konsep pelaksanaan tugas tersebut secara baik, agar dinamika tugas yang dilakukan berlangsung secara variatif dan didasarkan pada situasi dan kondisinya. Namun demikian, semua tugas yang dilakukan selalu disusun melalui program yang baik, pelaksanaan yang terukur, dan dilandasi rasa pengabdian serta motivasi yang tinggi.
Kepala sekolah sebagai penentu kebijakan di sekolah harus memfungsikan perannya secara maksimal dan mampu memimpin sekolah dengan bijak dan terarah serta mengarah kepada pencapaian tujuan yang maksimal demi meningkatkan kualitas dan mutu pendidikan di sekolahnya yang tentu saja akan berimbas pada kualitas lulusan anak didik sehingga bisa membanggakan dan menyimpan masa depan yang cerah. Sebagaimana yang dikatakan mantan Mendiknas Bambang Sudibyo, bahwa kuantitas siswa lulusan suatu sekolah ditentukan oleh mutu proses pengajaran maupun pengelolaan sekolah secara keseluruhan (Trianto, 2008, pp.3536).

Sejumlah pakar sepakat bahwa kepala sekolah harus mampu melaksanakan pekerjaannya sesuai kebutuhan masyarakat dan perkembangan zaman sebagai edukator, manajer, administrator dan supervisor serta mampu berperan sebagai leader, inovator dan motivator di sekolahnya, yang disingkat EMASLIM. Dan berkembang menjadi EMASLIM-F karena kepala sekolah juga sebagai pejabat formal.

\section{Kompetensi Kepala Sekolah}

Salah satu kompetensi yang harus dimiliki oleh kepala sekolah yaitu: "Kompetensi memiliki jiwa kepemimpinan", karena hubungan antara mutu kepemimpinan kepala sekolah dengan berbagai aspek kehidupan sekolah seperti disiplin sekolah, iklim budaya sekolah, dan menurunnya perilaku nakal siswa sangat erat sekali. Disamping 5 (lima) berupa: Kompetensi Kepribadian, managerial, kewirausahaan, supervisi, dan sosial. Kemampuankemampuan lain untuk mewujudkan keinginannya sebagai bekal seorang kepala sekolah, diantaranya:

- Mampu fisik dan mental.

- Mampu memilih strategi yang tepat untuk mencapai visi, misi, tujuan, dan sasaran sekolah.

- Mampu untuk mendorong perubahan sekolah (inovasi). 
- Mampu menggalang team work yang kompak, cerdas, dan dinamis.

- Mampu beradaptasi dan mengambil peran.

- Mampu mengambil keputusan secara cepat, dan tepat.

- Mampu berkomunikasi secara lancar.

Dari uraian di atas, kepala sekolah

harus benar-benar menjadi seorang inovator sejati, yang artinya tidak akan pernah merasa puas terhadap apa yang telah dicapainya, sehingga mendorong untuk senantiasa bergerak maju. Yang pada akhirnya sekolah dapat memenuhi kepuasan para stakeholdernya

Peran kompetensi kewirausahaan kepala sekolah untuk meningkatkan mutu pendidikan, dapat dilihat/diketahui melalui kerangka pikir penelitian dengan model CIPP (Context, Input, Process, Product).

Context untuk mengetahui relevansi kebijakan program dengan kebutuhan sekolah, Input untuk mengidentifikasi kesiapan sekolah, Process untuk mengetahui pelaksanaan kegiatan sekolah dan Product untuk mengetahui seberapa besar manfaat bagi peningkatan mutu sekolah.

Pelaksanaan peran kompetensi kewirausahaan kepala sekolah, memberikan kesempatan bagi guru, pegawai tata usaha, stakeholder sekolah, dan peserta didik untuk melaksanakan tugas dan fungsi sesuai perannya masing-masing. Program kompetensi kewirausahaan kepala sekolah yang dirancang diperuntukkan bagi peran kepala sekolah, guru, pegawai tata usaha, stakeholder sekolah, dan peserta didik untuk berinovasi, dan kreativitas. Diharapkan peran kompetensi kewirausahaan kepala sekolah ini dapat memenuhi kebutuhan layanan pendidikan yang memadai di SMP Negeri 3 Jetis, Bantul, Yogyakarta. dengan program-programnya sehingga dapat tampil beda dengan sekolah lain. Sejauh ini peran kompetensi kewirausahaan kepala sekolah, diselenggarakan oleh kepala sekolah di sekolah-sekolah formal di berbagai jenjang pendidikan.

Pelaksanaan peran kompetensi kewirausahaan kepala sekolah, mengacu kepada Permendiknas No. 13 tahun 2007, tentang Standar Kompetensi Kepala Sekolah/Madrasah sbb:

- Menciptakan inovasi yang berguna bagi pengembangan sekolah.

- Bekerja keras untuk mencapai keberhasilan sekolah sebagai organisasi pembelajar yang efektif.

- Memiliki motivasi yang kuat untuk sukses dalam melaksanakan tugas pokok dan fungsinya sebagai pemimpin satuan pendidikan.

- Pantang menyerah dan selalu mencari solusi terbaik dalam menghadapi kendala yang dihadapi sekolah.

- Memiliki naluri kewirausahaan dalam me-ningkatkan mutu pendidikan.

Wacana Entrepreneurship SMP tidak terlepas dari peran kompetensi kewirausahaan kepala sekolah SMP tersebut. Kompetensi kewirausahaan yang dimiliki seorang kepala sekolah akan sangat menentukan kegiatan inovasi sekolah yang dipimpinnya dalam rangka pengembangan sekolah, dan peningkatan mutu sekolah. Terlebih saat kepala sekolah, guru, dan tenaga kependidikan lainnya diajak untuk memperhatikan perubahan yang terjadi pada sekolah, kian terpacu untuk mengeksplorasi kewirausahaan sekolah, yang dapat dimanfaatkan siswa untuk memiliki kemampuan/kompetensi yang memadai.

Peran kepala sekolah menjadi amat penting, guna memajukan dan mengembangkan sekolah. Peran memiliki pengertian bahwa, tingkah laku yang diharapkan oleh orang lain terhadap seseorang sesuai kedudukannya dalam suatu sistem. Peran dipengaruhi oleh keadaan sosial baik dari dalam maupun dari luar dan bersifat stabil (Barbara : 2008).

Perilaku individu dalam kesehariannya hidup bermasyarakat berhubungan erat dengan peran, karena peran mengandung hak dan kewajiban yang harus dijalani seorang individu dalam bermasyarakat. Sebuah peran harus dijalankan sesuai dengan norma-norma yang berlaku, juga di masyarakat. Seorang individu akan terlihat status sosialnya dari peran yang dijalankan dalam kesehariannya. 
Dalam pada itu, untuk melihat lebih jauh tentang kompetensi kepala sekolah. Menurut Mulyasa, (2004, p.38), yang dimaksud dengan kompetensi adalah penguasaan terhadap suatu tugas, keterampilan, sikap, dan apresiasi yang diperlukan untuk menunjang keberhasilan. Hal itu menunjukkan bahwa kompetensi mencakup tugas, ketrampilan sikap dan apresiasi yang harus dimiliki kepala sekolah, untuk dapat melaksanakan tugas sesuai dengan jenis peker-jaan tertentu.

Agar pelaksanaan Peran kompetensi kewirausahaan kepala sekolah, dapat digambarkan dengan sistematis dan terukur, penelitian ini menggali persepsi warga sekolah atau stakeholder tentang Peran kompetensi kewirausahaan kepala sekolah, dilihat dari setiap aspek program, yaitu context, input, process, and product dalam pelaksanaan program di SMP Negeri 3 Jetis Bantul, Yogyakarta. Aspek konteks dibatasi pada masalah dukungan pemerintah, masyarakat, penyelenggara/pengelola sekolah. Aspek input dibatasi pada karakteristik siswa, kompetensi guru, kurikulum dan sarana prasarana, aspek proses dibatasi pada proses pembelajaran dan pengelolaan administrasi pembelajaran, aspek output dibatasi pada prestasi akademis dan non akademis.

Berdasarkan wawancara awal kepada kepala sekolah SMP Negeri 3 Jetis, Bantul tanggal 9 Agustus 2011 di SMP Negeri 3 Jetis, Bantul, juga ditemukan belum maksimalnya pelaksanaan program sekolah. Indikasinya: (1) pengunjung perpustakaan jumlahnya sedikit (antara tiga sampai dengan lima siswa/hari), (2) sekolah belum memiliki rencana pelaksanaan dan pengembangan kompetensi kewirausahaan kepala sekolah secara komprehensip. (3) masih adanya jam-jam pelajaran tidak efektif karena berbagai kendala, dsb.

Karena adanya masalah di atas, maka perlu diteliti penyebab keberhasilan kepala sekolah dalam menjalankan perannya sebagai pemimpin pendidikan. Kepala sekolah, sebagai motor penggerak peningkatan kualitas pendidikan di sekolah, perlu memahami cara-cara pembentukan dan pengelolaan kompetensi kewirausahaan kepala sekolah (Aan Komariah, 2006, p.113). Salah satu upaya yang dapat ditempuh adalah dengan merevitalisasi kewirausahaan sekolah yang bersumber pada nilai-nilai manajemen berbasis sekolah, etos kerja, dan integritas seluruh elemen sekolah. Kompetensi kewirausahaan kepala sekolah diharapkan mampu memberikan kontribusi secara maksimal terhadap upaya peningkatan mutu pendidikan.

Pada wacana Entrepreneurship SMP tidak terlepas dari peran Kompetensi Kewirausahaan Kepala Sekolah SMP tersebut. Kompetensi Kewirausahaan yang dimiliki seorang Kepala sekolah akan sangat menentukan kegiatan inovasi sekolah yang dipimpinnya dalam rangka pengembangan sekolah, dan peningkatan mutu sekolah. Terlebih saat kepala sekolah, guru, dan tenaga pendidikan lainnya diajak untuk memperhatikan perubahan yang terjadi pada sekolah, kian terpacu untuk mengeksplorasi kewirausahaan sekolah, yang dapat dimanfaatkan siswa untuk memiliki bekal di bidang wirausaha setelah tamat dari bangku SMP.

Kewirausahaan dalam konteks kompetensi kewirausahaan Kepala sekolah yang diambil adalah karakteristiknya/sifatnya seperti inovatif, bekerja keras, motivasi yang kuat, pantang menyerah, selalu mencari solusi terbaik, dan memiliki naluri kewirausahaan, bukan mengkomersilkan sekolah dan bukan berorientasi pada profit. Semua karakteristik tersebut bermanfaat bagi peran Kepala sekolah, dalam mengembangkan sekolah dan meningkatkan mutu sekolah. Untuk mencapai keberhasilan sekolah, melaksanakan tugas pokok dan fungsi sebagai pemimpin, menghadapi kendala sekolah, dan mengelola kegiatan sekolah sebagai sumber belajar siswa di SMP Negeri 3 Jetis, Bantul, Yogyakarta

Penelitian ini bertujuan untuk mengetahui : 1) persepsi warga sekolah terhadap dukungan pemerintah, masyarakat, dan penyelenggara/pengelolaan sekolah; 2) persepsi warga sekolah terhadap karakteristik siswa, kompetensi guru, kurikulum 
dan sarana prasarana program sekolah, 3) persepsi warga sekolah terhadap proses pembelajaran dan pengelolaan administrasi pembelajaran sebagai implementasi kompetensi kewirausahaan KS, dan 4) persepsi warga sekolah terhadap prestasi akademis, dan non akademis peserta didik.

\section{Metode Penelitian}

Jenis Penelitian

Jenis penelitian yang digunakan yaitu jenis penelitian deskriptif dengan pendekatan kualitatif. Tujuan untuk menggambarkan pelaksanaan program sekolah dilihat dari komponen Context, Input, Process, dan Product (CIPP).

Waktu dan Tempat Penelitian

Penelitian dilakukan selama 2 bulan, yakni sejak awal bulan Desember 2012 sampai dengan akhir Januari 2013. Didahului pra penelitian dari awal bulan Juli 2012 sampai dengan Agustus 2012. Penelitian ini dilakukan di SMP Negeri 3 Jetis, Jl. Parangtritis km 14,5 Patalan, Jetis, Bantul, Yogyakarta.

\section{Subjek Penelitian}

Subjek penelitian terdiri atas pengurus/ketua komite sekolah 1 (satu) orang, siswa/i sebanyak 5 (lima) orang, kepala sekolah 1 (satu) orang, wakil kepala sekolah 1 (satu) orang, dan guru berprestasi tingkat Nasional 2 (dua) orang, Jumlah total responden 10 (sepuluh) orang. Penelitian ini berusaha mencermati para informan secara teliti dengan cara berupaya menemukan informasi dari informan yang paling mengetahui topik yang diteliti.

Data, Intrumen, dan Teknik Pengumpulan Data

Data yang dibutuhkan yaitu data tentang: 1) Konteks (context) relevansi program telah sesuai dengan kebutuhan sekolah dengan indikator adalah (a) dukungan pemerintah, (b) manajemen kepala sekolah, (c) dukungan stakeholder, komite sekolah, dan (d) komitmen pengelola tentang peningkatan mutu pendidikan. 2) Input (input) berupa kesiapan sekolah seperti: sarana prasarana, guru, siswa, dan kepala sekolah untuk melaksanakan program dan sasaran yang jelas, dengan indikator : (a) karakteristik siswa, (b) karakteristik guru, (c) karakteristik kurikulum, dan (d) ketersediaan sarana-prasarana pendidikan. 3) proses (process) partisipasi guru, partisipasi siswa, dan partisipasi stakeholder lainnya aktif, kualitas KBM meningkat, dan kepala sekolah mampu memanajemen semua kegiatan sekolah. Dengan indikator: (a) administrasi kegiatan belajar mengajar (KBM), dan (b) kegiatan belajar mengajar (KBM), (c). Kegiatan ekstrakurikuler, 4) produk (product) dengan indikator: (a) prestasi akademik siswa (b) prestasi non akademik siswa, (c) angka drop out rendah, (d) angka siswa tinggal kelas rendah.

Instrumen yang digunakan mengumpulkan data yaitu berupa dokumentasi, pedoman observasi, dan pedoman wawancara.

Data dikumpulkan dengan cara, mewawancarai pengelola sekolah yakni kepala sekolah, wakil kepala sekolah, guru, dan tenaga kependidikan lainya, ketua komite sekolah, serta siswa-siswi, juga mempelajari dokumen Sekolah di SMP Negeri 3 Jetis, Bantul, Yogyakarta.

\section{Teknik Analisis Data}

Analisis data kualitatif dilakukan dari hasil wawancara diuraikan secara deskriptif dalam bentuk pembahasan. Analisis dilakukan untuk menggambarkan konteks, input, proses dan produk. Analisis data yang didapat dari hasil wawancara, observasi dan dokumentasi dianalisis secara kualitatif deskriptif melalui tahapan reduksi data, penyajian data dan penarikan kesimpulan atau verifikasi (Huberman dan Miles (1992, p.23).

\section{Hasil Penelitian dan Pembahasan}

Deskripsi data konteks yang akan diuraikan meliputi deskripsi konteks. Data 
diperoleh dari 10 responden penelitian, dengan hasil sebagai berikut:

\section{Program}

Konteks: Relevansi Program dengan Kebutuhan Bidang Akademik

Tabel 1. KKM tiap Mata Pelajaran di SMP N 3 Jetis, Bantul.

\begin{tabular}{|c|c|c|c|c|c|}
\hline \multirow{2}{*}{ No } & \multirow{2}{*}{ Mata Pelajaran } & \multicolumn{3}{|c|}{ Kelas/KKM } & \multirow{2}{*}{ Ket } \\
\hline & & VII & VIII & IX & \\
\hline 1 & 2 & 3 & 4 & 5 & 6 \\
\hline 1 & $\begin{array}{l}\text { Pendidikan } \\
\text { Agama }\end{array}$ & 75 & 75 & 75 & \\
\hline 2 & Pkn & 75 & 75 & 75 & \\
\hline 3 & B. Indonesia & 75 & 75 & 75 & \\
\hline 4 & B.Inggris & 70 & 70 & 70 & \\
\hline 5 & MTK & 70 & 70 & 70 & \\
\hline 6 & IPA & 70 & 70 & 70 & \\
\hline 7 & IPS & 70 & 70 & 70 & \\
\hline 8 & Seni Budaya & 75 & 75 & 75 & \\
\hline 9 & Penjasorkes & 70 & 70 & 70 & \\
\hline 10 & TIK & 75 & 75 & 75 & \\
\hline 11 & B.Jawa & 70 & 70 & 70 & \\
\hline 12 & PKK & & 75 & & \\
\hline 13 & Batik & 75 & & 75 & \\
\hline \multirow{3}{*}{14} & Pengembangan & Mini & Mini & Min & \\
\hline & Diri & mal & mal & imal & \\
\hline & & Baik & Baik & Baik & \\
\hline
\end{tabular}

Sumber: SMP Negeri 3 Jetis, Bantul

Dari Tabel 1 tersebut diketahui bahwa untuk Kurikulum yang dijalankan yakni: KTSP SMP N 3 Jetis, Bantul. Relevansi program telah sesuai dengan kebutuhan sekolah misalnya Program KKM tiap mata pelajaran contoh: Mata pelajaran Agama, PKn, Bahasa Indonesia, Seni Budaya, PKK dan TIK memiliki program KKM 75\% untuk kelas VII, VIII, dan IX. Program ini ditetapkan karena telah sesuai dengan kebutuhan dan target capaian kualitas sekolah dengan memperhitungkan kesiapan atau input sekolah, juga untuk mata pelajaran Bahasa Inggris, Matematika, IPA, IPS, Penjaskes, dan Bahasa Jawa memiliki program KKM 70\% untuk kelas VII, VIII, dan IX sudah memperhitungkan kesiapan dan kebutuhan sekolah. Sedangkan untuk mata pelajaran Pengembangan diri minimal baik. Konteks secara keseluruhan menunjukkan bahwa untuk peogram KKM cukup tinggi di atas 60\%. Hal ini berarti bahwa pelaksanaan Kurikulum dalam peran kompetensi kewirausahaan kepala sekolah dari sisi konteks secara keseluruhan telah dapat dilaksanakan dengan baik.

Termasuk dalam konteks yaitu dukungan dari pemerintah/dinas pendidikan, komite sekolah, dan stakeholder, serta komitmen dari pengelolanya. Secara faktual dukungan pemerintah yang dominan secara khusus lebih berupa legalitas formal perangkat peraturan dan perundangundangan yang menjadi dasar penyelenggaraan peran kompetensi kewirausahaan kepala sekolah di seluruh Indonesia. Bagi SMP N 3 Jetis, Bantul legalitas kepala sekolah untuk melaksanakan peran kompetensinya diperoleh melalui penunjukan AS sebagai kepala sekolah oleh Pemerintah melalui Dinas Pendidikan Kabupaten Bantul pada bulan Juli tahun 2010, dan pada saat itu implementasi manajemen melalui program-program sekolah di jalankan AS, dengan persiapan yang cukup seperti persiapan sarpras, persiapan tempat belajar, guru, kurikulum, pengelola, dan sebagainya untuk mengubah sistem sekolah dalam rangka peningkatan mutu pendidikan. Data input secara keseluruhan yang diperoleh melalui observasi, pencermatan dokumen dan dari 10 responden penelitian, diperolah hasil sebagai berikut:

Input: Kesiapan Sekolah seperti, Siswa, Guru, dan Siswa, untuk Program, dan Sasaran Jelas.

Tabel 2. Data Nilai Ujian Nasional Tertinggi dan Terendah Input Peserta Didik di SMP Negeri 3 Jetis, Bantul, YogyaKarta.

\begin{tabular}{ccccc}
\hline $\begin{array}{c}\text { Tahun } \\
\text { Pelajaran }\end{array}$ & $\begin{array}{c}\text { Men- } \\
\text { daftar }\end{array}$ & $\begin{array}{c}\text { Dite- } \\
\text { rima }\end{array}$ & $\begin{array}{c}\text { Nilai } \\
\text { Tertinggi }\end{array}$ & $\begin{array}{c}\text { Nilai } \\
\text { Terendah }\end{array}$ \\
\hline $2007 / 2008$ & 244 & 216 & 22,27 & 14,67 \\
$2008 / 2009$ & 344 & 216 & 26,90 & 21,05 \\
$2009 / 2010$ & 284 & 216 & 27,80 & 20,95 \\
$2010 / 2011$ & 270 & 216 & 26,90 & 19,60 \\
$2011 / 2012$ & 280 & 216 & 28,80 & 18,00 \\
\hline
\end{tabular}

Sumber : SMP Negeri 3 Jetis Bantul

Dari Tabel 2 diketahui bahwa input berupa kesiapan siswa. Pengertian siswa 
dimaksud (1) peserta didik yang tamat dari sekolah dasar, (2) peserta didik memiliki rentang usia 12 tahun sampai dengan 21 tahun, dan (3) peserta didik wajib belajar 9 tahun. Data menunjukkan bahwa dalam 5 tahun terakhir pendaftar yang ingin masuk pada sekolah tersebut, selalu meningkat sedang daya tampung stabil yakni 216 , hal ini kesiapan sekolah untuk peningkatan mutu pendidikan diperhitungkan sejak input dilakukan.

Tabel 3. Keadaan Tenaga Pendidik

\begin{tabular}{cccc}
\hline \multirow{2}{*}{$\begin{array}{c}\text { Pendidikan } \\
\text { Terakhir }\end{array}$} & \multicolumn{2}{c}{ Status Kepegawaian } & \\
\cline { 2 - 3 } & Guru & GTT/GB & \\
\hline S2 & 3 & - & 3 \\
S1 & 32 & 3 & 35 \\
D3 & - & - & - \\
D2 & 1 & - & 1 \\
D1 & - & - & - \\
Jumlah & 36 & 3 & 39 \\
\hline
\end{tabular}

Sumber : SMP Negeri 3 Jetis Bantul

Tabel 4. Sarana Sekolah 5 Tahun Terakhir

\begin{tabular}{clccc}
\hline No & \multicolumn{1}{c}{ Keadaan } & Jumlah & $\begin{array}{c}\text { Kon- } \\
\text { disi }\end{array}$ & Ket \\
\hline 1 & \multicolumn{1}{c}{2} & 3 & 4 & 5 \\
\hline 1 & Ruang Kepala Sekolah & 1 & Baik & \\
2 & Ruang Guru/TU & 1 & Baik & \\
3 & Ruang BP/BK & 1 & Baik & \\
4 & Ruang Belajar (Kelas) & 21 & Baik & \\
5 & Labolaturium & 2 & Baik & \\
& Komputer & & & \\
6 & Labolaturium IPA & 2 & Baik & \\
7 & Perpustakaan/R. AVA & 1 & Baik & \\
8 & Ruang Keterampilan & 1 & Baik & \\
9 & Ruang UKS/PMR & 1 & Baik & \\
10 & Mushola & 1 & Baik & \\
11 & Gudang & 2 & Baik & \\
12 & Kantin & 4 & Baik & \\
13 & Ruang Satpam & 1 & Baik & \\
14 & Toilet/Kamar Kecil & 13 & Baik & \\
15 & Lapangan Basket, & 2 & Baik & \\
& Volly, dan Area & & & \\
& parker & & & \\
\hline
\end{tabular}

Sumber : SMP Negeri 3 Jetis Bantul

Dari Tabel 3, menunjukkan bahwa input berupa kesiapan guru, jumlah guru 39 orang telah menyiapkan diri secara profesional untuk peningkatan mutu pendidikan di sekolah tersebut dikatakan bahwa:
"Guru yang bermutu tinggi sejak awal tidak perlu ditatar atau diikutkan dalam berbagai kegiatan, mereka akan mampu memahami dan menerjemahkan pesan-pesan kurikulum dengan cerdas. Mereka juga akan mampu mencari dan menemukan atau mengembangkan bahan ajar dan media pembelajaran yang bermutu, sekalipun tampa mengikuti penataran"(Veithzal Rivai dan Sylviana Murni, 2010, p.49).

Sedangkan Tabel 4, diketahui bahwa tingkat sarana prasarana menunjukkan kesiapan secara baik dalam menunjang peningkatan mutu pendidikan di SMP N 3 Jetis, Bantul diantaranya dengan eksistensinya 21 ruang kelas siap melayani proses pembelajaran dengan baik. dijelaskan bahwa:

"Sarana dan Prasarana pendidikan merupakan salah satu faktor utama yang mempengaruhi keberhasilan penyelengaraan pendidikan. Dengan adanya kerusakan sarana dan prasarana ruang kelas dalam jumlah yang banyak, maka bagaimana mungkin proses pendidikan dapat berlangsung secara efektif" (Veithzal Rivai dan Sylviana Murni, 2010, p.31).

Deskripsi data proses secara keseluruhan yang diperoleh dari 10 responden, diperoleh hasil sebagai berikut:

Proses: partisipasi guru, siswa, dan stakeholder lainnya aktif, kualitas KBM meningkat, kualitas kegiatan ekstrakurikuler meningkat, dan kepala sekolah mampu memanajemen semua kegiatan sekolah.

Hasil pengamatan kedisiplinan dan pelaksanaan tata tertib sebagai berikut:

Disiplin Siswa:

- Siswa mulai hadir pukul 06: 15.

- Pakaian yang digunakan adalah seragam sekolah,

- Mengucapkan salam kepada guru, Kegiatan yang dilakukan adalah melaksanakan kebersihan kelas, dan lingkungan sekolah.

- Pukul 07.00 WIB pelajaran dimulai, siswa/ siswi mengikuti pelajaran.

- Pukul 12.30 WIB siswa/siswi pulang, dan kelas yang memiliki jadwal les pelajaran tambahan melanjutkan kegiatan. 
Disiplin Guru:

- Guru-guru mulai hadir pukul 06:20.

- Pakaian yang digunakan adalah seragam guru.

- Pukul 07.00 WIB, Guru-guru masuk kelas melakssanakan KBM.

- Pukul 12.30 WIB, bel pulang guru meninggalkan ruangan kelas dan pulang

Hasil pengamatan kegiatan kebersihan kelas sebagai berikut:

- Pukul 06:30 para siswa/siswi mulai berdatangan

- Pukul 06:35 lima siswa/siswi petugas kebersihan mulai membersihkan kelas.

- Terlihat petugas piket kelas VIIA menyapu, membersihkan meja, dan membersihkan papan tulis.

- Hal serupa juga terjadi di kelas VIIIC, menyapu kelas, dan di kelas IXA siswa piket sedang menyapu kelas.

Dari hasil pengamatan tentang kedisiplinan siswa dan guru serta kegiatan kebersihan kelas, maka dapat diketahui bahwa dari sisi proses telah dilaksanakan dengan baik.

Proses atau process kompetensi kewirausahaan kepala sekolah SMP N 3 Jetis, Bantul, ditekankan kepada keterlaksanaan proses pembelajaran yang dilakukan oleh guru di kelas. Pelaksanaan pembelajaran sehari-hari di SMP N 3 Jetis, Bantul, telah sesuai dengan rancangan penyelenggaraan PBM yang disusun oleh seksi kurikulum sekolah sesuai dengan kewenangan yang ditetapkan oleh pemerintah. Masalah kedisiplinan akan waktu dan ketertiban lingkungan ditekankan sebagai budaya sekolah. Faktor kebiasaan dalam kegiatan keseharian di sekolah menjadi sangat penting, karenanya siswa diberi Pendidikan karakter bangsa yang setara dengan perkembangan zaman. Untuk membentuk watak, perilaku, dan budaya sekolah.

Meskipun demikian, sekolah tetap memberikan kesempatan yang luas kepada kepala sekolah, dan pengelola pendidikan lainnya untuk mengembangkan budaya sekolah di SMP N 3 Jetis, Bantul, Yogyakarta, dan kepada para guru pengampu tiap mata pelajaran untuk menyiapkan silabus, program semester, rencana pelak- sanaan pembelajaran, lembar kerja siswa, dan penilaian pembelajaran sebagai kelengkapan pembelajaran minimal.

Proses pembelajaran yang dimaksud dalam PBM yaitu proses atau kegiatan (Sebagai model layanan pendidikan standar di SMP N 3 Jetis, Bantul, Yogyakarta, untuk peningkatan mutu akademik khususnya, dan peningkatan mutu pendidkan pada umumnya.

Peran kompetensi kewirausahaan kepala sekolah termasuk di dalamnya menangani pengelolaan PBM, pengelolaan manajemen mutu terpadu, dan manajemen sekolah sebagai upaya kepala sekolah dalam peningkatkan mutu pendidikan di SMP N 3 Jetis, Bantul, Yogyakarta. Deskripsi data produk secara keseluruhan yang diperoleh dari 54 responden penelitian, diperelah hasil sebagai berikut:

- Produk Prestasi akademik, prestasi non akademik, prestasi lomba, dan peningkatan sarpras

Tabel 5. Rata-rata Nilai UN Output Peserta Didik SMP Negeri 3 Jetis Bantul

\begin{tabular}{cccc}
\hline $\begin{array}{c}\text { Tahun } \\
\text { Pelajaran }\end{array}$ & $\begin{array}{c}\text { Jumlah } \\
\text { Peserta } \\
\text { Ujian }\end{array}$ & $\begin{array}{c}\text { Jumlah } \\
\text { Peserta } \\
\text { Lulus }\end{array}$ & $\begin{array}{c}\text { Rata } \\
\text {-rata } \\
\text { UN }\end{array}$ \\
\hline $2007 / 2008$ & 229 & 218 & 6,50 \\
$2008 / 2009$ & 238 & 227 & 6,71 \\
$2009 / 2010$ & 208 & 207 & 6,87 \\
$2010 / 2011$ & 212 & 211 & 6,91 \\
$2011 / 2012$ & 214 & 214 & 6,83 \\
\hline
\end{tabular}

Sumber : SMP Negeri 3 Jetis Bantul

Dari Tabel 5 diketahui bahwa pada Tahun Pelajaran 2011/2012 tingkat kelulusan Ujian Nasional siswa $100 \%$. Hal ini berarti produk menunjukkan hasil memuaskan. dengan demikian peran kompetensi kewirausahaan kepala sekolah di SMP N 3 Jetis, Bantul, Yogyakarta, dari sisi produk secara keseluruhan telah dapat dikatakan baik. 
Tabel 6. Prestasi Siswa

\begin{tabular}{|c|c|c|}
\hline No & Jenis kegiatan & Prestasi \\
\hline & Lomba MTQ SMP Kabupaten & \\
\hline 1 & $\begin{array}{l}\text { Bantul (Putra) } \\
(2007)\end{array}$ & Juara 1 \\
\hline & Lomba Geguritan Kabupaten & \\
\hline 2 & $\begin{array}{l}\text { Bantul(Putri) } \\
\text { (2007) }\end{array}$ & Juara 3 \\
\hline 3 & $\begin{array}{l}\text { Lomba Penulisan Mading } \\
\text { Bahasa Inggris Provinsi DIY } \\
\text { (2007) }\end{array}$ & $\begin{array}{l}\text { Juara } \\
\text { harapan } 1\end{array}$ \\
\hline 4 & $\begin{array}{l}\text { Lomba Gerak jalan SMP } 1 \text { Jetis } \\
\text { (Putri) } \\
\text { (2008) }\end{array}$ & Juara 1 \\
\hline 5 & $\begin{array}{l}\text { Lomba lari } 100 \text { meter POR } \\
\text { Kabupaten Bantul } \\
\text { (2008) }\end{array}$ & $\begin{array}{l}\text { Juara } \\
\text { Harapan } 1\end{array}$ \\
\hline 6 & $\begin{array}{l}\text { Lomba Kader Kesehatan } \\
\text { Remaja Kabupaten Bantul } \\
\text { (2008) }\end{array}$ & Juara 2 \\
\hline 7 & $\begin{array}{l}\text { Lomba Cipta Cerpen } \\
\text { Kabupaten Bantul } \\
\text { (2008) } \\
\text { Lomba Cipta Puisi Kabupaten }\end{array}$ & Juara 3 \\
\hline 8 & $\begin{array}{l}\text { Bantul } \\
(2008) \\
\text { Lomba Mading Kabupaten }\end{array}$ & Juara 2 \\
\hline 9 & $\begin{array}{l}\text { Bantul } \\
(2010)\end{array}$ & Juara 2 \\
\hline 10 & $\begin{array}{l}\text { POR Pelajar Kabupaten } \\
\text { Bantul Cabang atletik } 100 \mathrm{~m} \\
\text { Putri } \\
(2010)\end{array}$ & juara 2 \\
\hline 11 & $\begin{array}{l}\text { POR Pelajar Kabupaten } \\
\text { Bantul Cabang Renang Gaya } \\
\text { Bebas } 400 \text { m Putra } \\
\text { (2011) }\end{array}$ & Juara 2 \\
\hline 12 & $\begin{array}{l}\text { POR Pelajar Kabupaten } \\
\text { Bantul Cabang Renang estafet } \\
\text { gaya ganti } 400 \mathrm{~m} \text { putra } \\
\text { (2011) }\end{array}$ & Juara 2 \\
\hline 13 & $\begin{array}{l}\text { POR Pelajar Kabupaten } \\
\text { Bantul Cabang Renang Gaya } \\
\text { Kupu-Kupu Putra } \\
\text { (2011) }\end{array}$ & Juara 3 \\
\hline 14 & $\begin{array}{l}\text { POPDA DIY Cabang Olah } \\
\text { Raga Renang Estafet Gaya } \\
\text { Ganti } 400 \text { m Putra } \\
\text { (2012) }\end{array}$ & Juara 3 \\
\hline 15 & $\begin{array}{l}\text { O2SN Kabupaten Bantul } \\
\text { Cabang Olah Raga Catur } \\
\text { (2012) }\end{array}$ & Juara 1 \\
\hline
\end{tabular}

Sumber : SMP Negeri 3 Jetis Bantul
Tabel 7. Prestasi Guru

\begin{tabular}{|c|c|c|}
\hline $\mathrm{No}$ & Nama Guru & Prestasi \\
\hline 1 & $\begin{array}{l}\text { Drs. Heri } \\
\text { Prasetya, M.Pd } \\
\text { (2006 -sekarang) }\end{array}$ & $\begin{array}{l}\text { Instruktur dan Tim } \\
\text { Pengembang KTSP } \\
\text { Nasional Direktorat } \\
\text { PSMP }\end{array}$ \\
\hline 2 & $\begin{array}{l}\text { Drs. Heri } \\
\text { Prasetya, M.Pd } \\
\text { (2006) }\end{array}$ & $\begin{array}{l}\text { Juara } 2 \text { Guru prestasi } \\
\text { Kabupaten Bantul }\end{array}$ \\
\hline 3 & $\begin{array}{l}\text { Drs. Heri } \\
\text { Prasetya, M.Pd } \\
\text { (2009) }\end{array}$ & $\begin{array}{l}\text { Juara } 2 \text { Guru Prestasi } \\
\text { Kabupaten Bantul }\end{array}$ \\
\hline 4 & $\begin{array}{l}\text { Drs. Heri } \\
\text { Prasetya, M.Pd } \\
\text { (2010) } \\
\text { Drs. Heri }\end{array}$ & $\begin{array}{l}\text { Juara } 1 \text { Lomba kreasi } \\
\text { dan inovasi Media } \\
\text { Pembelajaran Nasional } \\
\text { Juara } 2 \text { lomba kreasi }\end{array}$ \\
\hline 5 & $\begin{array}{l}\text { Prasetya, M.Pd } \\
\text { (2011) }\end{array}$ & $\begin{array}{l}\text { dan inovasi Media } \\
\text { Pembelajaran Nasional }\end{array}$ \\
\hline 6 & $\begin{array}{l}\text { R. Agus } \\
\text { Purnama, S.Pd } \\
\text { (2007) }\end{array}$ & $\begin{array}{l}\text { Juara } 2 \text { Guru Prestasi } \\
\text { Kabupaten Bantul }\end{array}$ \\
\hline 7 & $\begin{array}{l}\text { R. Agus } \\
\text { Purnama, S.Pd } \\
\text { (2009) }\end{array}$ & $\begin{array}{l}\text { Juara } 2 \text { Lomba Kreasi } \\
\text { dan Inovasi Media } \\
\text { Pembelajaran Nasional }\end{array}$ \\
\hline 8 & $\begin{array}{l}\text { R. Agus } \\
\text { Purnama, S.Pd } \\
\text { (2010) }\end{array}$ & $\begin{array}{l}\text { Juara } 1 \text { Guru Prestasi } \\
\text { Kabupaten Bantul }\end{array}$ \\
\hline 9 & $\begin{array}{l}\text { R. Agus } \\
\text { Purnama, S.Pd } \\
(2010) \\
\text { R. Agus }\end{array}$ & $\begin{array}{l}\text { Juara } 1 \text { Guru Prestasi } \\
\text { provinsi DIY }\end{array}$ \\
\hline 10 & $\begin{array}{l}\text { Purnama, S.Pd } \\
\text { (2010) }\end{array}$ & Guru Prestasi nasional \\
\hline 11 & $\begin{array}{l}\text { R. Agus } \\
\text { Purnama, S.Pd } \\
\text { (2010) }\end{array}$ & $\begin{array}{l}\text { Juara Harapan } 2 \\
\text { Lomba kreasi dan } \\
\text { inovasi Media } \\
\text { Pembelajaran Nasional }\end{array}$ \\
\hline 12 & $\begin{array}{l}\text { R. Agus } \\
\text { Purnama, S.Pd } \\
(2011)\end{array}$ & $\begin{array}{l}\text { Juara } 1 \text { Lomba Kreasi } \\
\text { dan Inovasi Media } \\
\text { Pembelajaran Nasional }\end{array}$ \\
\hline
\end{tabular}

Sumber : SMP Negeri 3 Jetis Bantul

Produk pendidikan tidak cukup hanya dilihat dari aspek akademik, tetapi juga aspek non akademik. Aspek non akademik tidak bisa hanya dilihat dari berbagai kejuaraan atau lomba yang dimenangi siswa lihat Tabel 6, dan 7 tetapi juga harus dilihat dari aspek perkembangan kedewasaan. Terkait dengan hal ini, hasil penelitian mengungkapkan fakta bahwa siswa lebih dewasa dilihat dari rasa tanggung jawab dan kematangan emosi. Temuan lain dapat dikatakan bahwa pembel- 
ajaran di kelas lebih menekankan pada aspek akademik, namun kurang menumbuhkembangkan sikap mental peserta didik, namun rasa tanggung jawab dan kematangan emosi. dapat ditutup melalui kegiatan non akademik, misalnya melalui kegiatan keagamaan di sekolah, dan terapan disiplin sebagai budaya sekolah. Stolp dan Smith (1995, p.12) mengatakan:

Culture represents a historically transmitted pattern of meaning embodied in symbols. Those symbols include both the written (explicit) and hidden (implicit) massages encoded in language some important elements of culture are norms, values, beliefs, traditions, rituals, caremonies, and myths translated by a particular group of people.

Sedangkan Haviland (1981, p.29) mengatakan:

Culture consists of the abstract values, beliefs, and perceptios of the world that lie behind people's behavior, and which that behavior reflect. these are shared by the members of a society, and when acted upon they produce behavior considered acceptable within that society.

Budaya adalah keseluruhan sistem berpikir, nilai, moral, norma, dan keyakinan manusia yang merupakan hasil dari interaksi manusia dengan sesamannya dan lingkungan alamnya termasuk hasil karya fisik seperti benda-benda yang digunakan dalam kehidupan manusia dan memecahkan persoalan kehidupan sehari-hari, dalam pada itu budaya sekolah menurut: Deal, Terrence E \& Kent D. Petersen (1999, p.2) mengatakan: "School have a culture that is definitelt their own. There are, in the school, complex ritual of personal relationship, a set of folkways, mores, and irrational sanctions, a moral code based upo them."

Budaya Sekolah adalah suasana kehidupan sekolah yang didasari oleh nilainilai, keyakinan-keyakinan, adat istiadat, kebiasaan-kebiasaan, norma-norma yang berlaku dan digunakan sebagai spirit dalam berperilaku, berinteraksi yang ditampakkan oleh warga sekolah secara konsisten dalam kehidupan baik di sekolah maupun di luar lingkungan sekolah untuk menghadapi dan memecahkan persoalan kehi-dupan sehari-hari serta mengambil keputusan yang tepat. Ada relevansi temuan lapangan dengan kajian teori yang ada.

\section{Simpulan dan Saran}

\section{Simpulan}

Berdasarkan diskripasi data, dan uraian tentang gambaran umum sekolah dapat disimpulkan sebagai berikut:

Konteks (Context) meliputi adanya indikator: (a) dukungan pemerintah, (b) dukungan dewan sekolah dan / komite sekolah, (c) dukungan masyarakat sekitar sekolah, dan (d) komitmen pengelola. baik kepala sekolah, dewan guru, dan staff. Indikator tertinggi komitmen pengelola ditandai dengan manajemen sekolah yang akuntabel, kredibel, dan partisipatif sedangkan terendah pada dukungan masyarakat sekitar ditandai dengan kurang kepedulian serta kurang aktifnya toga, dan tomas masyarakat sekitar sekolah tersebut.

Input (Input) meliputi adanya indikator: (a) karateristik siswa, (b) karakteristik guru, (c) karekteristik kurikulum dan (d) ketersediaan sarana prasarana pendidikan. Hal ini berarti bahwa pelaksanaan Peran kompetensi kewirausahaan kepala sekolah di SMP N 3 Jetis, Bantul, Yogyakarta, dari sisi input telah dapat dilaksanakan dengan baik. Namun masih ada guru yang direkrut tidak melalui seleksi dan tidak melalui pelatihan terlebih dulu. Semua guru menyatakan bahwa mereka telah menggunakan strategi kegiatan belajar mengajar yang menarik dan mudah dimengerti siswa,. beberapa siswa menyatakan bahwa ada guru yang tidak menguasai materi pelajaran.

Proses (Process) meliputi indikator: (a) administrasi KBM, dan (b) kegiatan belajar mengajar (KBM) menunjukkan hasil hasil memuaskan ditandai dengan meningkatnya kelu-lusan siswa yang hingga tahun pelajaran 2011/ 2012 mencapai 100\%. di SMP N 3 Jetis, Bantul, Yogyakarta. Dari sisi proses secara keseluruhan telah dapat dilaksanakan dengan baik. Demikian halnya dengan budaya sekolah dengan kegiat- 
an non akademik mampu menumbuhkembangkan sikap mental, rasa tanggung jawab, dan kematangan emosi. peserta didik dalam meraih prestasi.

Produk (Product) meliputi indikator: (a) ujian/tes formatif, (b) ujian/tes semester, (c) ujian sekolah, (d) ujian nasional, dan (e) prestasi kegiatan ekstrakurikuler menunjukkan hasil yang memuaskan, Hal ini berarti bahwa pelaksanaan peran kompetensi kewirausahaan kepala sekolah dari sisi produk telah dapat dikatakan baik. Hasil ujian nasional pada tahun pelajaran 2011/2012 dapat mencapai 100\%, dan evaluasi prestasi kegiatan ekstrakurikuler, tidak bisa hanya dilihat dari berbagai kejuaraan atau lomba yang dimenangi siswa Dilihat dari aspek non akademik lainnya yaitu dari sisi tanggung jawab, kestabilan emosi, dan perkembangan kedewasaan siswa.

Saran

Peningkatan kualitas peran kompetensi kewirausahaan kepala sekolah harus selalu ditingkatkan dengan cara melalui workshop kepala sekolah, atau pelatihanpelatihan profesionalisme kekepalasekolahan, sedangkan Peningkatan kualitas SDM, khususnya guru-guru, pengelola PBM merupakan salah satu faktor penentu keberhasilan program. Oleh karena itu, pengembangan kompetensi guru dalam hal penguasaan metodologi, penciptaan media pembelajaran, pengembangan kurikulum melalui pelatihan atau workshop rutin, dan berkelanjutan perlu dibudayakan sebagai salah satu prioritas.

Kegiatan sekolah non akademik khususnya kegiatan ekstrakurikuler dalam berbagai jenis kegiatan bagi semua siswa hendaknya tetap berjalan, dan selalu ditingkatkan agar peserta didik berkembang secara utuh.
Pencatatan administrasi kegiatan belajar mengajar di kelas yang oleh sebagian guru sering dilupakan hendaknya tidak diabaikan di setiap kelas, karena itu merupakan bukti legal formal yang penting untuk tertib administrasi dan dokumentasi sekolah.

\section{Daftar Pustaka}

Deal, Terrence E. \& Kent D. Peterson. (1999). Shoping school culture. The heart of leadership. San Francisco: Jossey Bass Publishers.

Haviland, W. A. (1981), Cultural anthropology. New York: Holt, Rinehart and Winston.

Mulyasa, (2004), Kurikulum berbasis kompetensi, konsep, karakteristik dan implementasi. PT. Remaja Rosdakarta Offset, Bandung.

Miles, M. B. \& Huberman, A. M. (1984). Qualitative data analysis.A. sourcebook of new methods. London New Delhi: Sage Publications Beverly Hills

Stolp, S \& Smith, S. C. (1995) Transforming school culture stories, symbolic, values $\mathcal{E}$ leader's role. Eugene ERIC, Clearinghouse on Educational Management University of Oregen. New York: University of Oregen.

Veithzal Rivai dan Sylviana Murni, (2010) Education management, analisis teori dan praktik, Rajawali Pers, Jakarta.

Depdiknas (2007), Permendiknas No. 13 tentang kompetensi kepala sekolah Direktorat Tenaga Kependidikan, Direktorat Jendral Peningkatan Mutu Pendidik dan Tenaga Kependidikan, Departemen Pendidikan Nasional, Jakarta. 